\title{
Perlindungan hukum pelaku usaha komoditi pertanian melalui penguatan anggaran dalam rangka mencegah krisis pangan
}

\author{
Miftakhul Irfan.
}

Miftakhul Irfan; Magister Hukum Universitas Brawijaya; Jalan MT. Haryono 169 Malang; 65145; JawaTimur; Indonesia.

\begin{tabular}{l}
\hline A R T I C L E I N F O \\
\hline Article history: \\
Received 2021-05-24 \\
Received in revised form \\
2021-07-04 \\
Accepted 2021-08-01 \\
\hline
\end{tabular}

Kata kunci:

Perlindungan Hukum; Komoditi; Pertanian.

\section{Keywords:}

Law Protection; Commodity;

Agriculture.

DOI: https://doi.org/10.26905/

idjch.v12i2.5809.

\section{How to cite item:}

Irfan, M. (2021). Perlindungan hukum pelaku usaha komoditi pertanian melalui penguatan anggaran dalam rangka mencegah krisis pangan. Jurnal Cakrawala Hukum, 12(2), 187-194. doi:10.26905/idjch.v12i2.5809.

Corresponding Author:

* Miftakhul Irfan.

E-mail address: mib.lawfirm2014@gmail.com.

\begin{abstract}
Abstrak
Besarnya pengaruh ketersediaan pangan serta keterjangkauan harga akan memberikan kepastian kepercayaan rakyat kepada negara, khususnya pemeritntah Indonesia yang memiliki Pancasila sebagai dasar manifestasi kehidupan berbangsa dan bernegara, harus diterjemahkan supaya dapat dipahami misi utamanya. Di dalam pendekatan semangat negara hukum, perlindungan hukum bagi jaminan ketersediaan pangan harus diperhatikan, sehingga tujuan utama dibentuknya negara untuk kesejahteraan rakyat dapat terwujud dan dirasakan. Demokrasi ekonomi yang berlandaskan keadilan sosial yang sudah diterjemahkan oleh pakar dan ahli hukum ekonomi menjadi model ekonomi kerakyatan memiliki kerangka yang harus diperjelas. Keberadaan negara agraris mengharuskan adanya kosentrasi pada sektor pertanian. Persoalan menyusutnya lahan pertanian produksi pangan dibandingkan luas lahan kelapa sawit merupakan wujud melemahnya peran pemerintah. Sehingga stimulus terhadap pertanian harus dilakukan. Penerapan harga pokok produksi pangan serta adanya jaminan harga terendah sangat dibutuhkan. Tentu dengan penjelasan utuh bahwa persoalan pangan bukan hanya jaminan pasokan. Namun kemampuan negara melakukan produksi secara mandiri menjadi kunci kedaulatan Negara.
\end{abstract}

\section{Abstract}

The magnitude of the influence of food availability and affordability of prices will provide certainty for the people's trust in the state, especially the Indonesian government, which has Pancasila as the basis for the manifestation of national and state life, must be translated so that its main mission can be understood. In the spirit of a rule of law approach, legal protection for the guarantee of food availability must be considered, so that the main objective of forming a state for the welfare of the people can be realized and felt. Economic democracy based on social justice, which has been 
translated by economic experts and lawyers into a popular economic model, has a framework that must be clarified. The existence of an agricultural country necessitates a concentration on the agricultural sector. The issue of shrinking agricultural land for food production compared to the area of oil palm land is a manifestation of the weakening role of the government. So that the stimulus to agriculture must be carried out. The application of the cost of food production as well as the guarantee of the lowest price is urgently needed. Of course with a complete explanation that the food problem is not just a guarantee of supply. However, the state's ability to produce independently is the key to state sovereignty.

\section{Latar Belakang}

Dunia sedang berjag-jaga dari kemungkinan terbesar datingnya krisis pangan. Sebagai negara agraris, Indonesia berpeluang menjadi pemain kunci di bidang pangan dunia. Adanya UndangundangNomor 18 Tahun 2012 Tentang Ketahanan Pangan yang memberikan peringatan akan adanya bahaya Krisis Pangan. Selain itu, adanya jenis-jenis pangan tertentu yang dilindungi serta pangan pokok akan ditetapkan sebagai item yang menjadi komoditas pertanian.

Adanya pengaturan tentang pangan pokok dan harga pangan pokok dari segi peraturan memang terlihat semangatnya, namun tidak pada kenyataan di lapangan. Fluktuasi harga murah setelah panen membuat petani gurem menjadi semakin sulit. Pupuk yang semakin mahal tidak dibarengi dengan harga jual panen yang bagus. Seringkali pemerintah harus melakukan operasi pasar disaat harga melonjak tinggi. Hal tersebut tidak berdampak pada kesejahteraan petani.

Sehingga dibutuhkan regulasi lanjutan untuk mensejahterakan petani gurem, yaitu petani penggarap atau pemilik lahan maksimal 2 hektar. Penetapan harga pokok pembelian hasil komoditas pertanian secara khusus harus dilakukan untuk memproteksi petani gurem tersebut agar berdaya. Mubyarto, mengupas secara mendalam pengembangan dari konsep tentang ekonomi pancasila, selain itu, koperasi sebagai wujud nyata amanat Pasal 33 Undang- Undang Dasar ndonesia Negara
Republik 1945 dan ekonomi pancasila adalah wujud gagasan Hatta untuk mewujudkan kesejahteraan rakyat. Persoalan krisis ekonomi 1997 dan krisis ekonomi dunia tahun 2008, akhir-akhir ini dialog tentang demokrasi ekonomi jarang ditemui. Resiko memiliki wilayah teritorial luas dan penduduk terbesar dunia terus adalah bagaimana menciptakan kesejahteraan rakyat dengan cara menjaga ketahanan pangan secara mandiri dan menyediakan energi secara melimpah.

Ekonomi kerakyatan dikenalkan sebagai perwujudan ekonomi pancasila. Ekonomi pancasila dianggap banyak diselewengkan oleh rezim orde baru, sehingga diperlukan konsep baru yang populer namun tetap konsisten pada pancasila. pada tahun 1979 hingga 1981, maka dicetuskannya ekonomi kerakyatan. Asas dari ekonomi kerakyatan diambil dari "kerakyatan yang dipimpin oleh hikmat kebijaksanaan dalam permusyawaratan/perwakilan."

Dunia sedang mengalami persoalan serius, yaitu persoalan efek perubahan iklim bumi dan dampak semakin sedikitnya energi fosil. Tentu saja berdampak pada tata kelola ekonomi Indonesia. Era modern yang datang bersama dengan permasalahan yang ada, akan memberikan pilihan yang tidak mudah sebagai negara agraris penghasil pangan dan energi, sebagai masyarakat dunia, Indonesia akan menjadi obyek utama dari efek emisi gas, krisis energi fosil dan kebutuhan pangan dunia serta peledakan penduduk. Fakta yang terkini saja, kekeringan sebagai akibat perubahan iklim dunia 
menimpa banyak negara di kawasan khatulistiwa dan negara berkembang.

Pada tanggal 12 Desember 2015 PBB bersama 196 negara dunia sepakat bahwa konferensi paris sebagai bentuk komitmen dunia untuk mengurangi emisi gas. Dunia telah menyepakati adanya efek kenaikan iklim diakibatkan industri energi fosil, peternakan, transportasi dan segala hal yang menyebabkan kenaikan emisi gas dan rumah kaca. Efek perubahan iklim sangat berpengaruh pada sektor pertanian, peternakan serta perkebunan. Kemarau panjang dan bencana alam diakibatkan badai darat dan laut langsung berdampak pada ketersediaan pasokan bahan makanan. Saat harga kebutuhan pokok melonjak naik, diakibatkan kelangkaan pasokan kebutuhan pangan, disitu akan hadir persoalan lain berupa kriminalitas dan inflasi kebutuhan pangan. Kelaparan akan berakibat pada resiko krisis ekonomi dan krisis keamanan.

Tantangan dan persaingan di sektor pertanian, perkebunan, peternakan khususnya penghasil energi hayati nampaknya akan semakin keras. Beberapa jenis tanaman selain menjadi konsumsi manusia, juga dikonsumsi oleh hewan produksi daging seperti jagung dan kedelai. Persoalan lain adalah kelangkaan energi fosil. Adanya penemuan teknologi alternatif sangat dibutuhkan oleh rakyat supaya pemanfaatan energi hayati untuk menopang perkembangan industri energi, transportasi dan pasokan pangan dapat hadir di masyarakat. Sejarah memberikan pelajaran penting tentang harus dijaganya ketahanan pangan.

Kemakmuran yang di asosiakan ke dalam bentuk konsep Ekonomi Kerakyatan kemudian perdebatan memunculkan konsep Ekonomi Kerakyatan, yang dimaksud adalah pembangunan ekonomi sebuah negara bertujuan hanya sematamata untuk kesejahteraan rakyat yang memiliki taraf hidup yang layak. Tercukupi pangan dan harga yang terjangkau. Tugas negara dalam hal ini spesifik, menjadi tugas pemerintah, menjadi penanggung jawab utama untuk mensejahterkan rakyat. Ada juga yang berpendapat bahwa pembangunan ekonomi Indonesia tidak berpihak pada ekonomi rakyat. Solusi dari persoalan tersebut dengan melakukan pembangunan dengan konsep ekonomi kerakyatan.

Melalui proses melibatkan lebih banyak rakyat dalam bidang ekonomi dan perdanganan (Manan, 2004). Indonesia memiliki peluang besar dalam percaturan ekonomi dunia ke depan sebagai pemasok pangan dan energi. Komoditas pangan di Indonesia lebih dikenal dunia, dengan sektor tanaman tertentu berskala besar menjadi sumber pendapatan ekonomi yang sangat besar. Misalkan komoditi kelapa sawit, energi hayati sudah mampu berpengaruh besar di pasar biofuel Uni Eropa.

Industri Komoditi dan Energi Hayati (Biofuel) satu kesatuan ekonomi utama di dunia saat ini. Dimana langsung berurusan dengan kebutuhan konsumsi manusia. Tingkat konsumsi manusia pada bahan makanan yang menjadi komoditiunggulan diperebutkan juga oleh industri energi hayati. Biji-bijian seperti kedelai dan jagung menjadi bahan utama biofuel, juga bahan utama makanan untuk peternakan di China dan Amerika. Komoditi gandum yang merupakan bahan utama pembuatan roti dan mie, menjadi sangat dibutuhkan di India dan Eropa. Secara umum, dunia juga mengetahui bahwa masyarakat timur tengah adalah penyuka daging dan roti. Indonesia dan Malaysia sebagai satu-satunya negara pemasok biofuel dari CPO (crudepalmoil) bisa jadi terhidandar dari kompetisi pangan dunia.

Namun bukan berarti tidak memiliki persoalan yang besar. Melalui kebijakan Uni Eropa, larangan pasokan CPO yang berasal dari Deforestasi menjadi ancaman serius pada 2030. Persoalan yang harus diselesaikan oleh Uni Eropa adalah alternatif pengganti $\mathrm{CPO}$, dimana Eropa menggunakan lebih dari $45 \%$ bahan baku biodisel dari CPO. Persoalan utama dari pembagian industri komoditiakan mempersulit kondisi saaat ini, dan akan datang. Pangan untuk manusia, biji-bijian untuk ternak dan 
pada situasi tersulit biji-bijian untuk bahan baku energi.

Pada tanggal 1 september 2015, pemerintah secara resmi memberlakukan kebijakan pemakaian B20 sebesar 20\% Fame dengan memberlakukan Perpres Nomor 66 tahun 2018 perubahan atas perpres Nomor 61 Tahun 2015 Tentang Perhimpunan dan Penggunaan Dana Perkebunan Kelapa Sawit. Selain aturan pelaksanaan tersebut, Kementerian ESDM memperkuat dengan Permen Nomor 41 tentang Penyediaan dan Pemanfaatan Bakar Nabati (BBN) Jenis Biodisel dalam Kerangka Pembiayaan oleh Badan Pengelola Dana Perkebunan Kelapa Sawit. (BPDKS) untuk bahan bakar nasional.

Persoalan krisis pangan kiranya menjadi satu design pengelolaan konflik baru dalam mengendalikan arah kebijakan sebuah negara. Secara global, krisis pangan dunia yang terjadi kurun waktu 20072010 menerpa sebagian besar negara-negara di benua Amerika. Lonjakan harga jagung, gandum serta biji-bijian disusul makanan produksi negara tropis juga naik seperti kopi, kapas, kakao dan gula menjadi dua kali lipat. Disisi lain, Lembaga pangan dunia (FAO) merilis angka kelaparan dan kekurangan gizi dunia antara 879 juta yang diturunkan dari 1 milyar, dikarenakan adanya perubahan metode penghitungan yang baru.

China dan India sebagai negara terbesar penduduknya, namun dalam konteks pangan dunia memiliki perbedaan cukup besar. Dari latar belakang agama, tentu India mayoritas adalah vegetarian. Berbeda dengan China yang mayoritas penikmat daging. Persoalan yang muncul dimana konsumsi biji-bijian begitu besar di China. Artinya kebutuhan jagung dan kedelai sangat besar untuk pakan ternak. Pembagian komoditi tersebut antara konsumsi manusia dan bahan pokok energi hayati (biofuel) saling bersaing. Sedangkan di India, kebutuhan akan gandum dan minyak sawit sangat besar. Di Afrika dan timur tengah, gelombang krisis keamanan gencar terjadi misalkan di Mesir, tunisia, maroko juga Turki. Mayoritas negara Arab memang melakukan kebijakan pangan murah dengan tujuan mencegah gejolak politik yang didorong dari mahalnya bahan makanan. Dimana kita ketahui, masyarakat timur tengah sangat konsumtif dalam urusan daging dan gandum juga bijibijian. Persoalan akan menjadi berbeda jika pasokan makanan terhambat dan menjadi mahal. Akan mudah terjadi gejolak krisis kemanan dan krisis politik.

Kesadaran pentingnya membuat payung hukum khususnya sektor pangan, energi dan pertanian tersebut berdasarkan pengalaman selama sepanjang peristiwa depresi ekonomi 1929-1933, krisis ekonomi global 2008. Krisis di Indonesia era Soekrano hingga kita mengenal gunting Syarifudin, krisis ekonomi 1998, hingga kemampuan Indonesia terhindar dari bahaya krisis dunia tahun 2008. Ternyata UMKM yang telah melaksanakan tugas dan fungsinya dengan sangat baik, menjaga kekuatan ekonomi mikro dan kecil Indonesia dari kehancuran ekonomi. (Ganindha, R., \& Sukarmi, S., 2020)

Hal yang paling membahayakan di tengah perebutan hegemoni ideologi liberal dan sosialis, pelemahan sebuah negara akan dipersulit dengan sulitnya pasokan makanan dan minimnya lapangan kerja. Dikhawatirkan akan terjadinya krisis keamanan, disitegrasi bangsa yang mengakibatkan memudarnya kekuatan dan pengaruh Amerika di dunia. Kesadaran negara dengan luas wilayah dan jumlah penduduk terbesar di dunia tidak akan terlepas dari persoalan ketahanan pangan, lebih populer komoditas pertanian.

Era kemajuan teknologi industri, beberapa tanaman pangan digunakan juga untuk menghasilkan energi hayati pengganti energi fosil. Ketika mengkaji persoalan energi, energi terbarukan yang berasal dari komoditas pertanian harus dibagi untuk energi dan pangan konsumsi manusia. Energi tersebut akan diperoleh dari komoditi jagung, kelapa sawit, tebu, kentang, gandum dan Bit serta kacang-kacangan. Tanaman tersebut akan 
menghasilkan Biofuel; Ethanol, Biodiesel. Sebagai alternatif energi fosil, persoalan yang timbul dikemdian hari berupa pembagian kebutuhan antara biofuel (energi hayati) dengan konsumsi manusia. Sehingga bahan bakar nabati tersebut diperebutkan oleh industri besar dan konsumsi manusia.

Undang-undang Nomor 18 Tahun 2012 Tentang Ketahanan Pangan telah diperkuat dengan dibentuknya UU nomor 19 Tahun 2013 tentang perlindungan dan pemberdayaan petani. Namun implementasinya sangat kurang, dimana peraturan tersebut hanya terfokus pada kondisi bencana, perubahan iklim kemudian adanya asuransi untuk petani yang masih membebani petani ke dalam biaya-biaya tertentu.

Peraturan tersebut seharusnya melindungi dan menjaga kepentingan petani gurem atau penggarap sawah di bawah dua hektar (2 hektar) yang telah ideal menurut Undang-undang nomor 19 tahun 2013 tentang perlindungan dan pemberdayaan petani. Artinya pernyataan Undangundang nomor 18 Tahun 2012 tentang Kedaulatan pangan yang mengamantkan secara kebijakan secara mandiri menentukan sistem pangan, menjamin hak dan menentukan sistem pangan sesuai potesi lokal. Kemudian diperkuat dengan adanya komitmen katahanan pangan untuk menjamin ketersediaan pangan yang cukup, bergizi, bermutu dan berkualitas bagus dan tidak bertentangan dengan hukum agama.

Secara simultan, peraturan tersebut runtut dan seharusnya membangun wilayah pertanian dan perkebunan menjadi lebih berdaya dan menghasilkan perbaikan ekonomi rakyat. Anggaran yang tidak di alokasikan secara khusus bagi petani gurem yaitu penggarap atau pemiliklahan 2 hektar, pelan tapi pasti akan merontokkan 35 juta petani di Indoneisa lebih maju dan sejahtera apabila saat datangnya masa sulit, krisis ekonomi atau inflasi yang menghancurkan penghasilan usaha tani. Oleh karena hal itulah perlu adanya penentuan Harga
Pokok bagi hasil dari produk pertanian tersebut agar perlindungan hukum dari petani mengenai harga akan terjamin dan tidak merugi.

\section{Metode}

Metode yang digunakan dalam penulisan ini merupakan penelitian hukum hukum normatif (yuridis normative) yaitu penelitian hukum dengan cara meneliti bahan kepustakaan dan peraturan perundang-undangan yang berlaku. (peter, 2005) Pengunaan jenis penelitian ini difokuskan pada UU Nomor 18 Tahun 2012 tentang pangan dan UU Nomor 19 tentang perlindungan dan pemberdayaan petani. Dimana konsepsi perlinduungan hukum terhadap usaha tani dan petani pada sektor komoditi pertanian dan perkebunan, serta energi hayati benar adanya.

\section{Pembahasan}

\subsection{Konsep Perlindungan Hukum Bagi Usaha Tani Pada Komoditas Pertanian Demi Terciptanya KesejahteraanRakyat}

Perlindungan Hukum menurut begawan hukum nasional, Soetjipto Raharjo merupakan upaya melindungi kepentingan seseorang dengan cara mengalokasikan suatu kekuasaan kepadanya untuk bertindak dalam kepentingan tersebut. Bahwa salah satu sifat dan sekaligus merupakan sifat sekaligus merupakan tujuan dari hukum adalah memberikan perlindungan kepada masyarakat. Oleh karena itu perlindungan hukum terhadap masyarakat tersebut harus diwujudkan dalam bentuk adanya kepastian hukum. (soetjipto, 1983)

Di dalam penjelasan Redjeki Hartono, bahwa perlindungan hukum merupakan permasalahan yang berkaitan dengan pemberian proteksi dan fasilitas kepada ekonomi lemah. Para pelaku ekonomi dari strata di bawah perlu mendapat proteksi terhadap pesaing-pesaing tidak setara. Di samping itu, agar benar-benar mampu bersaing 
dalam kesetaraan dan kejujuran juga dibutuhkan fasilitas akses modal. (Sri, 2007)

\subsection{Pemerintah Menetapkan Harga Pokok Produksi Pangan}

Sistem perdagangan pangan dunia yang semakin terbuka atau pasar bebas menyebabkan harga produk pangan di dalam negeri ikut terpengaruh oleh situasi dan kondisi harga internasional. Kondisi tersebut dan berbagai masalah ketersediaan dan distribusi, menyebabkan harga komoditas pangan, terutama pangan strategis seperti beras, kedelai, daging sapi, cabai dan bawang merah menjadi berfluktuasi. Indonesia sebagai negara agraris menghasilkan berbagai macam produk pangan strategis.

Agar produksi pangan dapat berkelanjutan, dan kebutuhan pangan masyarakat dapat terpenuhi, pemerintah harus melindungi masyarakat dan petani dari gejolak harga, seperti harga jatuh pada saat panen raya, dan harga melambung pada saat di luar panen. Salah satu upaya yang dilakukan pemerintah adalah dengan kebijakan stabilisasi harga pangan agar petani sebagai produsen mendapatkan hasil yang menguntungkan, dan masyarakat sebagai konsumen mampu membeli bahan pangan dengan harga yang terjangkau.

\subsection{Penetapan Harga Pembelian Pemerintah (HPP) Gabah/Beras}

Salah satu masalah klasik yang sering dialami petani padi adalah anjloknya harga jual gabah/ beras pada saat panen raya, dan meningkatnya harga pada saat diluar panen. Kondisi tersebut menyebabkan petani menjadi rugi dan usaha tani padi tidak menguntungkan. Selain itu, kenaikan harga beras dapat menimbulkan gejolak social mengingat beras merupakan makanan pokok masyarakat Indonesia. Oleh karena itu, pemerintah berupaya membuat regulasi/kebijakan perberasan agar gabah/beras petani dibeli dengan harga tertentu yang bisa memberikan keuntungan yang layak bagi petani. Selain itu, beras dijual kemasyarakat/konsumen diatur dengan harga tertentu sehingga masyarakat mampu mengakses dalam batas wajar.

Harga komoditas pangan yang selalu berfluktuasi dapat merugikan petani sebagai produsen, pengolah pangan, pedagang hingga konsumen dan berpotensi menimbulkan keresahan sosial. Fluktuasi pasokan dan harga pangan yang tidak menentu, tidak hanya akan menimbulkan keresahan sosial, tetapi juga akan mempengaruhi pengendalian inflasi. Kenaikan harga bahan pangan digolongkan sebagai komponen inflasi bergejolak (volatilefoods), karena sifatnya yang mudah dipengaruhi oleh masa panen, gangguan alam, harga komoditas bahan pangan domestik dan internasional. Oleh karena itu, hampir semua negara melakukan intervensi kebijakan untuk menjaga stabilitas harga pangan pokok dan strategis.

Harga dan pasokan pangan merupakan indikator-indikator strategis yang saling terkait dan sering digunakan untuk mengetahui: (a) status distribusi pangan, (b) permasalahan yang disebabkan oleh rantai distribusi pangan pokok yang tidak efisien mulai dari tingkat produsen sampai konsumen, dan (c) tidak cukupan pasokan pangan di suatu wilayah. Dalam konteks regulasi, guna mengatur dan menjaga stabilisasi pasokan dan harga pangan, telah terbit 2 (dua) Undang-Undang terkait stabilitas harga pangan, yaitu Undangundang Nomor 18 Tahun 2012 tentang Pangan dan Undang-Undang Nomor 7 Tahun 2014 tentang Perdagangan.

Pemerintah pusat dan daerah bertugas mengendalikan dan bertanggung jawab atas ketersediaan bahan pangan pokok dan strategis di seluruh wilayah Negara Kesatuan Republik Indonesia. Bahan pangan pokok dan strategis tersebut harus tersedia dalam jumlah yang memadai, mutu yang baik, serta pada harga yang wajar untuk 
menjaga keterjangkauan daya beli di tingkat konsumen sekaligus melindungi pendapatan produsen. Peningkatan harga komoditas pangan memang dapat berasal dari produsen, namun sumber peningkatan harga tersebut biasanya lebih bersifat fundamental karena di dorong oleh meningkatnya harga input/sarana produksi atau karena faktor kebijakan pemerintah seperti penetapan harga dasar (floorprice). Sementara peningkatan harga yang 2 didorong oleh faktor distribusi bersifat variabel, seperti panjangnya rantai jalur distribusi, hambatan transportasi dan perilaku pedagang dalam: menetapkan marjin keuntungan, aksi spekulasi maupun kompetisi antar pedagang. Tingginya volatilitas harga komoditas yang terjadi selama ini mengindikasikan bahwa faktor distribusi sangat berpengaruh.

Dalam mengamankan ketahanan pangan dan peningkatan pendapatan petani, beberapa masalah yang dihadapi dapat dikelompokkan sebagai berikut, yaitu (1) masih rentannya produksi padi sebagai akibat banyaknya bencana banjir dan tanah longsor yang terjadi pada tahun 2006; (2) rendahnya tingkat produktivitas ternak dan belum berfungsinya sistem kesehatan hewan nasional, terutama di daerah-daerah yang dapat mengganggu produksi dan keamanan pangan hasil ternak; (3) rendahnya tingkat produktivitas dan kualitas hasil perkebunan dan hortikultura meskipun luas lahan terus bertambah karena adanya investasi; (4) sistem penyuluhan yang belum berfungsi penuh di daerah-daerah yang masih perlu terus diperkuat untuk dapat memperlancar diseminasi dan penerapan teknologi produksi, pengolahan, dan peningkatan mutu hasil; dan (5) optimalisasi dan rehabilitasi lahan serta jaringan irigasi, jalan desa, dan jalan usaha tani yang masih memerlukan partisipasi masyarakat.

Langkah-langkah di atas akan didukung pula dengan pembaharuan agraria nasional dengan melanjutkan langkah (1) pengaturan penguasaan, pemilikan, penggunaan dan pemanfaatan tanah
(P4T); redistribusi tanah (termasuk pemetaan untuk mendukung Program Pembaharuan Agraria Nasional/PPAN) serta inventarisasi P4T; (2) pengendalian dan pemberdayaan kepemilikan

tanah di kabupaten/kota; dan (3) pengkajian dan penanganan sengketa dan konflik pertanahan di kabupaten/kota. Dalam rangka menjaga keberlanjutan usaha pertanian dan daya dukung alam dan lingkungan dilakukan langkah untuk meningkatkan kualitas pengelolaan hutan dan lingkungan melalui (1) pengendalian kebakaran hutan untuk menurunkan hot spot; (2) rehabilitasi hutan dan lahan dengan target tersusunnya rencana teknis rehabilitasi hutan dan lahan dan terselenggaranya rehabilitasi hutan di daerah rawan banjir; (3) pembangunan $\mathrm{KPH}$ dengan target ditetapkannya KPH model; dan (4) pengelolaan taman nasional model dengan target terwujudnya kelembagaan pengelolaan kolaboratif di taman nasional model, serta terlaksananya kegiatan pengembangan taman nasional dalam rangka debt nature swap (DNS).

Kebijakan tersebut dikenal dengan istilah Harga Pembelian Pemerintah (HPP) procurement price policy. Penetapan HPP dilakukan dalam rangka meningkatkan pendapatan petani, pengembangan ekonomi pedesaan, stabilitas ekonomi nasional, peningkatan ketahanan pangan, dan dalam rangka pengadaan cadangan pangan. Selain itu juga untuk mendukung peningkatan produktivitas petani padi dan produksi beras nasional. HPP gabah yang ditetapkan pemerintah diharapkan menjadi "semacam harga minimum" (floor price) yang berfungsi sebagai referensi harga (price reference) bagi petani dan pedagang yang melakukan transaksi jual-beli gabah/beras.

\section{Simpulan}

Negara sebagai pemangku kebijakan dari Konstitusi memiliki andil untuk melakukan rekayasa demi menghadirkan kepastian, perlindungan dan kesejahteraan hukum. Berdasarkan 


\section{Jurnal Cakrawala Hukum, Volume 12 No. 2 Agustus 2021}

ISSN PRINT 2356-4962 ISSN ONLINE 2598-6538

UU Nomor 18 tahun 2012 pasal 1 ayat 29 tentang krisis pangan, pasal 1 ayat 3 tentang kemandirian pangan, pasal 1 ayat 15 tentang pangan pokok dan harga pangan pokok mengamanatkan supaya pemerintah dan pemerintah daerah serius mengalokasikan dana. Hal tersebut diperkuat oleh UU Nomor 19 Tahun 2013 Tentang perlindungan dan pemberdayaan petani pasal 12 ayat 2 bahwa yang harus diberikan jaminan harga komoditas pertanian hanya petani-petani penggarap atau pemilik lahan maksimal 2 hektar.

Penerapan harga pokok produksi akan memberikan kepastian agar petani gurem tidak merugi. Apabila pada saat panen harga anjlok maka sisa kerugiannya akan dibayar oleh pemerintah dan pemerintah daerah. Di dalam pengelolaannya, penetapanHPP serta angka keuntungan petani di pusatkan pada pengelolaan yang baik dengan membentuk lembaga pengelola dana subsidi pertanian atau bekerjasama dengan koperasi yang sudah memiliki pengalaman cukup panjang mengurusi keuangan rakyat mikro.

\section{Daftar pustaka}

"19th Sessionofthe Conferenceof the Partiesto the UNFCCC". International Institutefor Sustainable Development. Diakses tanggal 01 Desember 2019.
Dewi, Kadek Ayu Novita Prahastha dan Santoso, Eko Budi. Pengembangan Komoditas Unggulan Sektor Pertanian Tanaman Pangan di Kabupaten Karangasem Melalui Pendekatan Agribisnis, Jurnal Teknik Pomits, Vol. 3, No. 2, (2014).

Edwards, Chris. 1998. Subsidipertanian. Wanghington D.C.: Downsizinggoverment.org.

Ganindha, R., \& Sukarmi, S. (2020). Peran pemerintah daerah dalam mendukung potensi indikiasi geografis produk pertanian. Jurnal Cakrawala Hukum, 11(2), 211-221. doi: https:/ / doi.Org/ 10.26905/ idjch.v11i2.3970.

Hartono, Sri Redjeki. 2007. Hukum Ekonomi Indonesia. Malang: Bayu media Publishing.

http:// www.cnnindonesia.com. larangan sawit ditunda 2030: Kamis, 28 juni 2018.

Karlyana, K. E., \& Mulyono, G. P. 2018. Legal Protection To The Pedestrian Right. Jurnal Pembaharuan Hukum, 5(2), 166-174.

Manan, Abdul. 2004. Peranan Hukum dalam Pembangunan Ekonomi. Jakarta: Kencana Prenada Media Group.

Muchsin. 2003. Perlindungan dan kepastian hukumbagi Investor di Indonesia Surakarta: MIH Program Pasca Sarjana UNS.

Peter Mahmud. 2005. Penelitian Hukum. Jakarta: Kencana Perdana.

Soetjipto Raharjo. 1983.Permasalahan Hukum di Indonesia. Bandung: Alumni. 